\title{
Cerebral Hemorrhage Related to Birth
}

National Cancer Institute

\section{Source}

National Cancer Institute. Cerebral Hemorrhage Related to Birth. NCI Thesaurus. Code C116909.

Intracranial bleeding in the tissue of the cerebrum of a newborn infant occurring during labor and/or delivery. 